\title{
EARLY EUROPEAN TRADE AMONG THE SOUTH AFRICAN BANTU, AND SOME SOCIAL CONSEQUENCES OF IT
}

\author{
Bertram Hutchinson \\ (Centro Brasileiro de Pesquisas Educacionais)
}

The study of culture contact is nowadays an accepted and a significant part of the field of studies in which the anthropologist works. We have many studies whose primary purpose has been the analysis of the process of acculturation, and, indeed, there must be few field anthropologists who have not been obliged to take account of culture contact (particularly with western culture) in the communities they study. But while the phenomena of culture contact are not new, the disciplined study of them is, and material collected in the field is almost entirely modern. If we are to learn anything of earlier processes of culture contact - and it is well to remember, for example, that contact between primitive communities and western society as we know it may have begun two centuries or more in the past - we must make use of documentary material from contemporary sources. We do not have such material for every society with which the west began contact in an earlier century. On the other hand, for some of them the material is quite rich, and readily avalable, one of these societies being that of the Bantu-speaking people of South Africa. I have therefore selected a restricted area of culture contact, that of European trading and the growth of new material wants amcng the Bantu, and I have attempted to reconstruct, from the historical material, the course of events and some of the social consequences which flowed from them. For it is only rarely that material innovations are not followed by a social aftermath. In South Africa the innovations were numerous, the forces behind them potent, and the social consequences of a corresponding gravity.

There were from the outset two principal and converging forces which gave rise new material wants among the Bantu. First, and possibly primary both in time and in importance, was the progressive shrinking of their economic resources following European settlement of the country. In the course of time the Bantu no longer possessed the means of supporting themselves exclusively by their traditional agricultural methods. What they could no longer produce for themselves they had 
to obtain by playing a part (albeit an irregular one) in the European economy. In a significant sense they were caught up involuntarily in the economic revolution. But it was not entirely unsought. In addition to these primary and objective pressures there were personal incentives which caused increasing numbers of the Bantu people to seek European goods not, or not merely, because they "needed" them, but because they "desired" them. One of the earliest, and one of the most direct, means by which these new wants were aroused is to be found in the commercial actirities of European traders.

It is curious to remember that the Colonial Government's policy during the early years of the 19th century was the discouragement of contact between European and African. In pursuance of this policy Europecn trading with the Bantu was prohibited. However, there were immense social and economic pressures working in favour of contact, and. by 1830 the Government was forced to compromise to the extent of permitting trading to Europeans who had been licenced and were of "good character"1. Even so, the number of licenced traders increased slowly, and eighteen years later, in 1848, there were only 38 of them in British Kaffraria, together with a few more who had pushed on into Natal. 2 Few in numbers though they were, the volume of trade with the Bantu people for which the traders were responsible grew steadily. By 1834 the value of trade on the eastern frontier approached $£ 40,000$ sterling per year ${ }^{3}$. Between 1799 and 1827 the export of hides from Cape Town increased from 2,500 to 75,000 annually, and the export of horn and ivory rose correspondingly. In 1828, the weekly fair at Grahamstown had brought about the barter of 3,380 pounds of beads; 46,373 dozen buttons, 3,249 pounds of brass wire (together with an indefinite number of knives, axes and tinder boxes), for 2,218 pounds of ivory, 20,572 hides and 78 cattle $^{4}$. The vigorous activity of this fair is well described by a missionary who visited it at this time:

\footnotetext{
"During the morning", he writes, "I witnessed ... the Caffre Fair, a market held weekly for barter with the natives. Nearly a thousand were present. The commodities brought by them were various; I noticed hides, horns, baskets, hats, mats and rims (or halters), birds, brooms, honey, corn, pumpkins and milk, together with ornaments of various kinds; all of which they were intent on getting changed for beads, buttons and brass wire. They manifested no great desire for clothes, nor do I think the fair will create in the Caffres a love for wearing apparel; this must be done by the influence of missionary stations, around which clothes are generally esteemed and sought after"s.
}

Meanwhile, on the eastern frontier trade was beginning to involve many more utilitarian articles. The Bantu people in increasing numbers were seeking such things as spades, hoes, blankets, tobacco, sugar, rice, 
and these were beginning to take the place of articles of luxury which for long had been a near-monopoly of chiefs and others of high status in the tribe. There is some evidence, indeed, that the earlier forms of trade involving luxuries (e. g. beads, wire, buttons), served to reinforce the status of traditional tribal authorities. This was most evident in Natal, where trade was closely restricted by the chiefs to themselves, the people as a whole having little interest in the matter. In any case, the main article of trade, ivory, was by tradition the property of chiefs, who saw the advantage of enforcing this privilege when the coming of European traders gave to the ivory an added value ${ }^{6}$. Beads, one of the most common articles which traders gave in exchange for African produce, were at first carefully adapted to traditional patterns of prestige:

" "The natives", wrote J. W. Colenso in 1855, "it appears, are as capricious in their taste for beads as any English lady in the choice of her bonnet ... One fine blue bead was oval, not round as it ought to have been, another black round one was a little too large. The choicest kind are the umGazi (blood), a small red bed;... a beautiful new sort has just come out, likely to have a large run; but Panda will not allow any of his people to buy any, until he has seen and approved the pattern... There is one large bead, like a pigeon's egg, which no-one but himself and his great captains are allowed to buy"7.

Many tribal chiefs were acutely conscious of the advantages they could derive from trade with the Europeans, and did much to encourage it, some making formal application to the Government for a resident trader $^{8}$. By 1847 the Government had fully reversed its earlier policy. The goal was now to introduce the Bantu as quickly as possible to European civilisction. Trade was to be given every assistance, and traders were urged "to teach the Kafirs the use of money, and to clothe themselves", and to bring for trade "not baubles and trash of beads", but articles of utility and agricultural implements ${ }^{9}$. The greater range of goods which thenceforward entered into trade was to have its own far-reaching effects upon the social organisation and system of values of the Bantu people.

It must be remembered that, for many Africans, the traders had a significance that was additional to their economic function. They represented close at hand an example of a new of life, and sometimes an avenue of escape for discontented Africans from the old ways to the new ${ }^{10}$. Perhaps the material aspects of their daily life hed at first little to attract, or even to interest, the observant African. An English traveller passing through the country in 1835 has described the traders' stations of the period as "wretched, mudbuilt hovels. . : with two rooms... an odoriferous melange of garbage, fat and filth...". ${ }^{11}$ Sociologically, however, they may have been more interesting to a people whose social. 
horizons had been narrow, and whose knowledge of other ways of life was correspondingly small. It was many years before traders felt their position suffciently secure to justify them in bringing European wives to live with them. In the meantime, many traders took African women as "wives", though on what terms of responsibility we do not know ${ }^{12}$. Contemporary travellfers were unanimous in accusing the Natal traders in particular of leading "immoral lives"; and Gardiner, who was not, like so many writers of the period, hostile to the Europeans, states that Natal traders were inducing Africans, especially young African women, to leave their tribes, secreting them "in their wagons and (conveying) them by stealth to Port Natal". ${ }^{13}$ Speaking generally, the behaviour of traders in all respects seems to have been somewhat in conflict with the Christian principles which were being disseminated at the same period by the missionaries. Indeed, the traders were accused of attempting deliberately to thwart missionary efforts. It is difficult to estimate how much weight we should give to such accusations. There is the contrary evidence that some traders, sensing in missionary education a means of increasing the desire among Africans for European goods, helped and encouraged the missicnary schools, and themselves "from principle... kept holy the Sabbath." 14 There is, nevertheless, at lecst the likelihood that a seeming disagreement between the system of values taught by the missionaries and that on which the traders ordered their lives was confusing to a people beginning to feel more strongly the impact of culture contact. Moreover, when eventually the European traders were accompanied by their European wives and children, in so doing they were displaying to the Bantu. a different form of crganised family life of the conjugal rather than the consanguine type with which the Bantu had hitherto been exclusively familiar.

The presence of the European trader, and the spectacle of his way of life, were probably in themselves factors disturbing to the equilibrium of Bantu life. And yet the impact of the different habits of life followed by small numbers of isclated traders cannot, by itself, have been great. The fact is that the traders were a vehicle by which a far more powerful force was brought to bear upon Bantu society: the growth of new material wants and the desire for their satisfaction. In comparison with European standards, the material level of Bantu life was low. Other African people with whom the Bantu may have been in contact had a material standard of life little different from their own; and, indeed, there were some, such as the Bushmen, who had an appreciably lower standard. Before the coming of the Europeans only in an abstract sense were the Bantu people poor. Since they had no means of compariscn, no knowledge of the heights which material life could reach, they were naturally satisfied with what they had. Bantu society was organised to make possible 
for all the satisfaction of a stringently limited range of wants within its framework. The wants which Bantu scciety stimulated in its members were those which, under carefully defined rules, could be easily satisfied. Individual differences in wealth, though they existed, were not great, and the disintegrating effects of envy and competition were largely absent. Relatively rigid forms of organisation ordered economic production and distribution (giving to the traditional ways the appearance, almost, of a law of nature), and it did not encourage the emergence of individual improvements in agricultural methods or pastoral yield. There were no doubt some individuals, as there are in any society, however rigid, who, to a limited extent, broke with tradition in order to further their own interest; but new desires could not emerge on a large scale where there was no means of satisfying them. It was European contact which showed the way to new satisfactions, and alternative ways of obtaining the old ones.

It fell to the individual, rather than to Bantu society as a coherent whole, to take advantage of the new opportunities. But in order to do this he had to break away, either permanently or temporarily, from tribal controls, for these did not encourage effort for ends in which personal advantage was dominant and community considerations made subordinate. The values of the new, European economy gave the traditional Bantu system of mutual cbligation (especially that part of it which required the son to give the utmost economic and social support to the father) the appearance of social parasitism. It was inconsistent with the individualist outlook which was becoming necessary if new desires were to be satisfied. Nor was the entry into the European eccnorny the outcome only of personaly covetousness, though this was stimulated by the traders. The purchase of goods was becoming necessary to the Bantu in order to make up the deficiency in their econcmy which followed the European disposession of Bantu land resources. The new economic wants were in this way given a dual aspect: communal in so far as their satisfaction contributed to family and tribal subsistence, and personal in the degree to which they were connected with personal satisfaction and prestige. In either case, however, as the original system of trade and barter by tribal representatives with Europeans gave way to a money economy which accompanied a growing need among Europeans for cheap labour, the acquisition of new matericl goods became an individual function.

The direct assaulit of the European economy was accompanied by the powerful influence of the Christian missions in spreading the knowledge of, and the desire for, western merchandise. Some of the missionstations set up a special section for trading with the African populatic ${ }^{15}$, and the annual turnover was sometimes quite considercble. It was 
especially characteristic, of course, that the missions inculcated a desire for westtern forms of clothing: in many areas such clothing was obligatory upon all Christian converts. For many years the adoption of western clothing was as much an article of faith as any of the more philosophic notions which the Christian missions were seeking to impart. Few, however, could afford to have more than a single set of European clothing, and opportunities for laundering were therefore rare. The celebrated remark of Kreli, a Xosa chief cf the 19th century, that he hated the smell of Africans who kept their western clothing on their unwashed bodies does more than merely indicate the growing schism within the Bentu community: it illustrates also the lack of foresight which the missions frequently displayed in their impatient desire for social change among the people they had taken under their care. For, unlike the Bantu blanket, European clothing cannot be easily put off, so Africans continued to wear it even after it was sodden with rain. The spread of tuberculosis and other respiratcry troubles, not to mention rheumatism, though no doubt largely the result of new infections, poor diet and bad housing conditions following European colonisation, was encouraged by the introduction of western clothing unaccompanied by either a proper knowledge of its limitations or a sufficient wardrobe. It is also worthy of note that the spread of disease had a further consequence: the need for European methods of medical treatment ${ }^{16}$.

The influence of the missionaries was not confined to the introduction of western clothing, for in addition to spiritual guidance, most missionaries gave instructicn to the people in the "useful arts". It was in any case necessary for missionaries to cultivate their land for their own subsistence; but there were some, especially the Moravian Brothers. who laid great emphasis upon the introduction to the Bantu people of new agricultural methods, and other practical matters. They tried to set an example to them in the growing of unfamiliar crops, in the use of new tools and in novel techniques like the digging of irrigation canals. Such examples were not by any means always followed, and, as we know, to the present day African agriculture remains underdeveloped. One tool, however, gained immediately in popularity: the plough; and because of the particular social consequences which flowed from its use it deserves special comment.

By 1861 there was a total of 528 ploughs in British Kaffraria (that is, excluding "the Colony") among a Bantu population estimated at some $72,000^{17}$, or one plough to approximately 136 persons. When it is considered that a considerable amount of borrowing within the kinship group probably went on, the changes that were occurring in Bantu methods of agriculture must have been large. But so revolutionary a change in agricultural technique clearly entails widespread social adjustment. 
The initial purchase of the plough must have contributed to family and sccial disturbance, for money had to be earned in distcnt work centres. Moreover, the use of the plough in cultivation depended upon the employment of cattle as draught animals; and the employment of cattle in this utilitarian way contradicted the traditional aura of symbolism and sentiment which, for the Bantu, surrounded these animals. Their use, moreover, entailed certain changes in the old forms of sexual division of labour. The cultivation of the fields had been women's work, and as such was derogatory to the dignity of men. Conversely, Bantu women were held to have a malign influence upon the cattle, especially during periods of menstruation, and were therefore to concern themselves as little as possible with them. It followed that, if the plough were to be employed in the fields, the men would have to use it, for it was unthinkable to allow women to work with the cattle, even in agricultural 1abour. The conflict was resolved, however, by the realisetion that, now that cattle had an important place in agriculture, the work was consequently ennobled to the extent that men no longer need feel shame in performing it. Under the influence of these new pressures men began to move out from the shade of their kraals into the fields, where they began to plough and sow, working side by side with their women; and in the course of time old forms of sexual division of labour became blurred ${ }^{18}$. And with this problem at least temporarily resolved, the demand for the plough increased, so that a trader in the Hart River district near Kimberley could claim that by 1876 he himself was selling them at the rate of one a day ${ }^{19}$.

\section{II}

Trade with the Bantu pecple had grown remarkably by the last quarter of the 19th century, when the mining industry was beg:nning to assume the dominating position in the South African economy which it has held ever since. Those tribes which had early placed themselves under the protection of the Colonial) Government, such as the "Fingoes", were buying European goods particularly readily. Western clothing was becoming indispensable. Paper collcrs were in especial demand. Some chiefs were having visiting cards printed. In some areas the traditional round hut was being replaced by the square house. In many Bantu homes, round or square, hinged doors were being fitted, with locks, - the symbol of the breakdown in mutual trust and in group sanctions. Government officials repcrted a growth in the desire for the acquisition of property, a keener sense of the value of money, and an understanding of the function of employment as a means of obtaining luxuries ${ }^{20}$. There were some cutstanding Bantu people coming to the fore who were suc- 
cessful almost entirely within the framework of European individualist values, like the following man, described in 1870 by a missionary ${ }^{21}$ :

"Mahanga is one of the best specimens of a thoroughly civilized and Christianised Tambookie Kaffir. Some twenty-four years ago he was a red-clayed and barbarous heathen; but now he lives in a large and beautiful house, which he has built at a cost of $£ 400$, on a splendid farm (in Glen Grey) of two thousand five hundred acres, with flocks and herds, etc., all his own, and surrounded by a loving family".

For the majority of the Bantu people, although it was by individual effort that trader's goods had now to be obtained (for the old system of barter was dying) with money obtained through working on European farms, in the diamond or gold mines, or in the towns, the process of purchase nevertheless often remained a matter of group interest. Personal prestige and group approval were still linked in a direct way which was later to disappear with the growth of personal anonymity in the urban centres. The following scene described by Sarah Heckford, a trader in the Transvaal in the eighties, succeeds, despite its air of condescension in giving us something of the atmosphere of this phase ${ }^{22}$ :

"“Some absurd looking savage in a blanket", she writes, "would ask to see a shirt, or a coat, or a pair of trousers, or perhaps a hat. The assembled multitude would become all attention. He would be turned round and round, the critics would fall back a pace or two, and look at him with thoughtfulness, while he watched their faces anxiously: No, there was a bulge at the back! or the brim was a little too narrow - he must try another. Or perhaps when the critics were satisfied, the purchaser would screw himself round, and gazing down his own back, would say, 'Don't you think it would be better if it were a little more this, or a little less that" and his friends would discuss the matter, gravely walking round him with their heads on one side, until it was settled to general satisfaction. The trying on of boots was very fine - the would - be purchaser often having very little on him except the boots. After pulling them on, he would promenade backwards and forwards in them, trying how they felt. When the purchase, whatever it might be, was concluded, the purchaser frequently celebrated the event by a 'breakdown' amid universal applause".

The individual was not yet as free of community opinion as he was to become, either in the purchase of European goods or in the adoption of European habits. He was still seeking community approval even though this was merely to improve his personal prestige within it. But this was decaying in places where men lived no longer among the tribe but among an aglomeration of individuals with a common habitat. African labour tenants, farm workers, mine workers and the growing number of urban dwellers, by the last decades of the 19th century, were living 
away from their tribes for long periods of the year, and some permanently. In such circumstances, purchases could be made in isolation. The employed Bantu tribesman was no longer directly guided by the opinions of his fellows, but by only his personal opinion as to the choice which would bring him the maximum social recognition and prestige. He could follow, if he wished, a more rapid rate of personal adjustment than was usual at home among the tribe. Moreover, prestige now had to be sought in the first place among the collection of individual workers in the labour centres, among whom vagaries of personality and personal taste were accorded a higher value than they were at home.

Meanwhile, the increasing degree to which the Bantu were entering the European economic nexus was accompanied by a decline in Bantu subsistence production. While the habits of tradition expected every Bantu household to produce most of what it required, there was now a growing tendency for European goods to take their place. Traditional family life was thus deprived of one its strongest cohesive forces as the old econcinic functions of the household were reduced in importance, or, in the towns and on the mines, disappeared completely. It was easier, when it was financially possible, for the African to buy his grain from the trader rather than to grow it himself. In any case, periods of drought, inefficient planting and, in latter years, loss of fertile land to the Europeans, made his own food supply irregular to the extent of causing periods of semi-starvation. Traders were not slow in extending credit facilities in order ultimately to increase their sales.
"It is no uncommon thing", wrote Sir John Robinson on conditions in Natal, "for them to pledge their crops beforehand, and this has an unfortunate effect upon their industry, for they say, 'Of what use is it to cultivate our fields well, their produce belongs to the storekeeper, not to us. I cannot but think that this disposition on the part of European tradesmen to prey upon the weakness and the cupidity of the natives by giving them credit, and inducing them to buy largely, will thus tend to check agriculture..."23.

Equally common was the extension of credit, with the family cattle as security. The people were becoming dependent upon the trader, not only for the satisfaction of desires they never had before, but also for the primary needs of subsistence. The degree of this dependence was dramatically revealed on th occasion of the rinderpest outbreak among Bantu cattle in 1899; and it also increased it. The rinderpest left the African "less independent, more inclined to work, less impudent and generally better in every way than he was before", wrote a contemporary administrator $^{24}$.

However this might be, there is little doubt that the expansion of money-lending facilities by traders throughout South Africa was, by 
the turn of the century, encouraging Bantu understanding of a money economy. For in addition to the crop credits which we have already noted, traders began to make money advances to people wishing to travel to the labour centres. Such advances were ostensibly to cover the expenses of travel, and were to be repaid out of the worker's first earnings. Very high rates of interest were charged, and so profitable did money lending become that traders devoted more attention to it than to ordinary business. Before long money was lent indiscriminately to anyone who applied, whether he was going away to work or not, mainly on the security of family cattle. Such sums, ranging in value from $£ 1$ to $£ 100$, were likely to be spent in the indulgence of personal wishes rather than in the support of family and community obligations, and Africans who were in a position of tribal responsibility watched the effects with dismay $^{25}$. In consequence, money lending was in later years subject to control, and by 1933 the sums involved, at least in the Transkei, were usually no more than $£ 3-£ 5$, such loans going mainly to "join-boys" recruited by traders for the mines ${ }^{26}$.

The social effects of money lending were considerable. The ease with which money could be obtained in this way was a powerful incentive to men to leave their community for the labour centres. Not only did it whet their appetite for European goods: it obliged them to go away in order to earn the money to repay the loan, for few were willing to forfeit the cattle they had given as security. Moreover, the loans themselves made it possible for poor men, who otherwise could not afford it, to face the expense of a long journey to the labour centres. Petty criminals, people who had incurred tribal displeasure, those who, for any reason, wished to desert their family and their tribe, could thus disappear in the anonymity of the railway. The disappearance was the more secure if, as was often done, a man took the precaution of borrowing money from a trader in a district in which he was not known. Again, at times of wedding festivities the bridegroom would seek an advance of money from the trader, ostensibly to defray the customary expenses of such celebrations. And yet an African Transkeian Councillor could complain:

"Children, youths and girls went to the stores when a wedding was about to take place, without informing their parents as to what they were about, but on the wedding morn a father would be astounded to see his son attired in the most foppish fashion, with a big collar that would stand up till sunset, tanned boots as if he were a theatrical artist about to do a stage turn, and everything else in keeping"'27.

Very often the consequence was that, immediatly after the marriage, the bridegroom went away to earn the money to repay the loan, leaving his father at home to provide for the bride, and handicapped for want of his son's help on the land. A father could obtain a loan on the security 
of his daughters if he had no cattle ${ }^{28}$, or on his sons if they seemed reasonably likely to go away to work. But although the authority of the Bantu father over his chiloren had been profound in the past, it was now weakening. Children were becoming unwilling to accept parental exploitation of them in such ways, just as the growing sense of personal responsibility and a desire for freedom from community and familial control were making them impatient of more traditional forms of duty to parents. An indirect result of indiscriminate traders' loans was therefore a protest against parental authority which took the active form of escape to the cities.

While the credit facilities themselves were increasing the familiarity of the Bantu people with European goods, this process wass extended further by a continuous increase in the number of traders concerned with the African market. For example, the number of trading stations in the Cape Colony, the Bechuanaland Native Reserves and the Transkei increased from 645 in 1903 to 827 in 1904 - an increase of twenty-eight per cent. within a year ${ }^{29}$. Despite the vigorous opposition of the Europeans, a few educated Bantu were by this time taking out licences in order to become traders themselves ${ }^{30}$. Business was profitable because many Bantu families were becoming, as we have seen, increasingly dependent upon the local store for at least part of their food, and upon wage-earning in order to pay for it. Without simple necessity as a goad, agriculture began to be neglected, and domestic producticn of goods fell off. Even tobacco was no longer domestically produced by 1904, but was bought from Asian immigrant growers ${ }^{31}$; and the role of the home as the place for eating meals began to be undermined by the growth of "Native Eating Houses", haunted by prostitutes, which were set up by Europeans, Asians and occasionally by Africans ${ }^{32}$. The combination of these various factors meant that in many Bantu households the housewife no longer had to work as hard as in the past ${ }^{33}$ : no new functions had so far taken the place of those which had decayed. But if the women had increased leisure, they had generally to spend it away from their husbands when the latter were absent earning money, and extra-marital sex relations became common. The position of wcmen was changing in another way, partly as a result of the expense of buying the European goods that were now become necessities, for husbands were finding that after paying for these they could not so easily afford the luxury of a second wife. The Chief Magistrate of the Transkeian Territories, reporting in 1902 on the fact that polygamy was "fast decreasing", said that monogamists in the Territories now outnumbered polygamists in the proportion cf three to one. He went on:

"...tribes which have been longest in contact with European civilisation are those among whose people the decrease of polygamy is most marked... in the Xalanga district the percentage of married 
men who are polygamists is only five, and eight in those of Butterworth and St. Marks, whereas in some districts where religious and other civilising influences are not so strong the percentages are as high as 30 and $33 " 34$.

\section{III}

It is evident in much of what we have been discussing that there are difficulties inherent in the use of historical material in the study of culture contact and culture change. The process of culture change is fundamentally indivisible, and the abstraction of certain phases of it for separate study has an air of unreality. So closely related functionally are the various phases of change that we are never wholly successful in examining one in isolation, while holding the others constant. It is almost inevitable in so doing that we go beyond the limits we have set ourselves in order to offer a full explanation of social change.

This is clear from our evidence on the effects of new material wants upon Bantu social organisation. It is possible to trace a threefold division of this process and its consequences. First there is the role of the traders as bearers or exemplars of new habits and behaviour. This seems to have been of greater importance in Natal where, as we have seen, traders lived with African women, and were the agencies by which people were moved from their tribe to the coastal areas. To a limited degree also the traders, through the example of their daily lives, were among the earliest sources from which the Bantu people could learn something of the culture of the Europeans. This first role, however, was really only incidental, and was not dependent upon the trading functions of the Europeans involved.

Secondly, there were the consequences which flowed from the acquisition of the new goods themselves. It seems likely that in the early phase of trading some of these goods (such as beads) could be, and were, used to reinforce traditional status within the tribe. This might have continued had it been possible for chiefs to maintain the limitation of trading to themselves. The forces of change, however, doomed this to an early failure. To the influence of the traders and of the missionaries, in inculcating a desire for European merchandise among the people generally, there was added the paramount fact of European colonisation. For this process, by depriving the Bantu people of sufficient land to support themselves entirely, made it necessary to make up the disparity from European sources. The necessity of supplementing their livelihood was one of the main reasons for the movement of tribesmen to the various labour centres throughout South Africa. But the introduction of the new goods in many cases, as we have seen, had profound social consequences. If the evidence were available, it might be possible to trace 
the social consequences of each of the range of European goods which the Bantu people were beginning to consume. In this paper we have taken a small number of examples as illustrations of the process. We have seen something of the effect of the introduction of western goods and of the rise of "eating-houses". In each case it has been clear that the. introduction of new goods, seemingly simple, had its sequel in social readjustment sometimes extensive, sometimes limited. In particular it seems to have been the primary units, the family (or kraal) and the kinship group, which were most affected. It is possible to see that the new goods alone were capable of destroying some of the foundations on which the family and the kinship group as an economic unit, and as an arbiter of individual behaviour, were built .

Thirdly, there were the indirect consequences of the rise of new material needs; and these were the most profound. The passing of the early barter method of exchange and the extension of a European money economy to include the Bantu people meant that money had to be earned if the new wants were to be satisfied. The family, and indeed the tribe generally, was split and shaken by the constant stream of men and women flocking to the towns and the minefields, temporarily or permanently, to earn money. This development and its consequences are familiar enough to need no reiteration here ${ }^{35}$. The tendency of the times was towards a realisation of a new way of thinking about economic needs and material wealth: that of individualism. The credit extended by the traders, the personal nature of earnings, the purchase of many goods for private rather than group satisfaction, the different speed at which the several members of a single family made themselves ready to accept novelties: all these factors, and others like them, were elevating the individual at the expense of the group from which he came. But the seed from which these changes sprang was sown by the traders, and by other agencies, who first inculcated among the Bantu people a desire for the new material wealth. Without this incentive the course of social change among them would have been very different.

\section{FOOTNOTES}

(1) Governor's Ordinance of December 23rd, 1830: Parliamentary Papers (Great Britain), 1835, xxxix (252), 615.

(2) The distance of Natal from the commercial centre at Cape Town at first limited trade in this territory. General trading was not developed for a number of years, the Zulu people, in the meantime, remaining largely unaffected by the new economy. See the report by Sir Benjamin D'Urban, Parliamentary Papers, 1835, xxxix (252), 630.

(3) Cambridge History of the British Empire, viii, 819.

(4) Bannister, S., Humane Policy; or Justice to the Aborigines of New Settlements, London, 1830, 110; 128. 
(5) Methodist Missionary Society, Notices, vi, 1829-1831.

(6) See Parliamentary Papers, 1835 , xxxix (252), 528, 588; also Isaacs, N., Travels and Adventures in Eastern Africa, London, 1836, ii, 34.

(7) Colenso, J.W., Ten Weeks in Natal, Cambridge, 1855, 30.

(8) For example, the case of the chief Dingaan: Parliamentary Papers, $1835, \operatorname{xxxix}(252), 588$.

(9) Government Notice, December 23rd, 1847: Parliamentary Papers, 1847-8, xliii (969).

(10) Traders frequently protected refugee Africans, and provided means for their transport to the coast. Parliamentary Papers, 1835, xxxix, $(252), 630$.

(11) Gardiner, A.F., A Journey to the Zoolu Country, London, 1836, 9-10.

(12) Periodical Accounts Relating to the Missions of the Church of the United Brethren, xxix, 176.

(13) Gardiner, A.F., op. cit., 208

(14) Report by the Wesleyan missionary, John Ayliff, in Parliamentary Papers, 1837, xliii (503), 554-5.

(15) Parliamentary Papers, 1836, vii (538), 93. Also see Bannister, S., op. cit., 130 .

(16) In the 'fifties of the last century the colonial administration sought io increase the demand among Africans for European medical treatment. The motive for this policy was not so much official benevolence as a feeling that it might increase African friendship for the Europeans. Charles Brownlee, a Colonial Commissioner, made special efforts during this period to induce as many Africans as possible to place themselves under the care of an army doctor. The policy was not unsuccessful. Within three months, in 1856 , over 2.000 Africans had sought medical treatment, many coming from distant parts of the Colony. (Parliamentary Papers, 1857, x, (2202), 456-458). The emergence, however slow, of this new habit had important consequences for the structure of traditional Bantu life, which had its own patterns for the treatment of sickness and the care of the sick. In these the witch doctor had a primary role, as he had in many other moments of social crisis. The witch doctor was a powerful and a conservative force which the Europeans were not unwilling to see destroved, and the efforts that were made to introduce the Bantu people to European medicine were influenced by the hope that this obstacle to European influences would be removed (Parliamentary Papers, 1856, xlii (2096), 341-343). But one of the most important results the coming of European medicine, apart from its effect upon the witch doctor's prestige, was the making of ill-health an individual matter, instead of the group or kinship problem it was traditionally thought to be.

(17) Parliamentary Papers, 1865, xxxvii (3436), 30.

(18) On the effects of the introduction of the plough, see, for example, the following: Junod. H.A., The Life of a South African Tribe, London, 1927, i, 538-9; ii, 48, footnote; Hunter, M., Reaction to Conquest, London, 1936, passim: Schapera, I., Married Life in an African Tribe, London, 1940, 131-2; 162 .

(19) Paliamentary Papers, 1877, 1x (C. 1776), 390.

(20) Cape of Good Hope, Blue Book on Native Affairs, G. 27. 1874,4; 59.

(21) Methodist Missionary Society Notices, 4th Series, ii, 133.

(22) Heckford, S., A Lady Trader in the Transvaal, London, 1882, $250-251$.

(23) Pobinson, Sir J., Notes on Natal, London, 1872, 48.

(24) Cape of Good Hope, Blue Book on Native Affairs, G. 31, 1889, 81. 
(25) For example, see the comments of Councillor Xabanisa in the Proceedings and Reports of the Transkeian Territories General Council, 1913, 26.

(26) Haines, E. S., "The Transkei Trader", South African Jour. Econ., i, $1933,211$.

(27) Councillor Mamba, reported in the Proceedings and Reports of the Transkeian Territories General Council, 1914, 39.

(28) Union of South Africa: Second-Sixth Report of the Select Committee on Native Affairs, S. C. 6.a 1917, 211.

(29) Cape of Good Hope, Blue Book on Native Affairs, G. 12, 1904, 151, $172,178,198$

(30) South African Native Affairs Commission, 1903-5, Minutes of Evidence, paragraphs 21,221-8.

(31) Ibid., paragraph $20,046$.

(32) Natal, Blue Book on Native Affairs, 1904, v.

(33) Cf. the evidence given by Sir James Hulett, former Natal Secretary for Native Affairs, to the South African Native Affairs Commission, 1903-5: Minutes of Evidence, paragraph 20,046. $47-48$

(34) Cape of Good Hope, Blue Book on Native Affairs, G.29, 1903,

(35) For example, consult Hellmann, E., "Native Life in a Johannesburg Slumyard", Africa, viii, 1935; Hunter, M., Reaction to Conquest, London, 1936; Rheinallt Jones, J.D., "Social and Economic Conditions of the Urban Native," in I. Schapera (ed.), Western Civilisation and the Natives of South Africa, London, 1934; Schapera, I., "Economic Changes in South African Native Life", Africa, i, 1928; Schapera, I., "Economic Conditions in a Bechuanaland Native Reserve" S.Afr. Jour.Sci., xxx, 1933; Schapera, I., Married Life in an African Tribe, London, 1940, especially Chapter v. 